\title{
Exploration of the Promoting of the Non-Tenure Track Position as a Means of Enhancing Teaching and Professional Effectiveness in Higher Education: A Reflective Case Analysis of Non-Tenure Track Position Model in a Private University
}

\author{
James M Mbuva \\ National University
}

The study promoted a non-tenure track position as a means of enhancing teaching and professional effectiveness in higher education using reflective case analysis of non-tenure track position model in a private university. Areas explored included: defining non-tenure track position, performance and the mistreatment of the non-tenured faculty, growth of non-tenure compared with a tenure-track position, what tenure-track position offers, how non-tenure and tenure track positions enhance teaching, scholarship, service and professional effectiveness, and personal reflections of non-tenured track professor at a private university in Southern California, USA. The study found that non-tenured faculty is as productive as the tenured faculty.

\section{INTRODUCTION}

The issue of tenure and non-tenure track in higher education is not a recent phenomenon (Keza \& Sam, 2011; Purcell, 2007; Musselin, 2007; West \& Curtis, 2006; Ehrenberg, \& Zhang, 2005; Cross \& Goldenberg, 2003; Harper, et al., 2001; Nestor, \& Leary, 2000; McPherson \& Schapiro, 1999). Irrefutably, employees would like to see their jobs well secured over the years of their employment whether in private or public universities. However, at the same time, there is a need of looking for an alternative approach such as nontenure which reviews the value of evaluating ones work after every year, two years, three years, and use the results of performance to determine the longevity of employment.

Indeed, this study uses a reflective case study of the researcher to show the value and effectiveness of non-tenured track. The research presented the problem statement, examined the definition of non-tenure track position, and the performance and the mistreatment of the non-tenured faculty. The study showed the growth of non-tenure compared with a tenure-track position, presented what tenure track offers, and demonstrated how non-tenure track position enhances teaching and professional effectiveness in higher education. Further, the research used the author's personal reflections of non-tenured track professor in a private university in California, explained that non-tenured teaching position job security is assured though performance. The study delved into compensations and the faculty evaluation process in place to ensure non-tenure track position security. Finally, the study ended with conclusions and recommendations. 


\section{PROBLEM STATEMENT}

With the inherent conflict that exists between tenure and non-tenure positions (Haviland, Alleman, \& Allen, 2017; Chait \& Chait, 2002; Maid, 2001; Brown \& Kuhand, 1990), it is vital to have an in-depth analysis to bring out the radical distinctions of these two tracks that are like brothers, yet they are not friendly. Indeed, the tenure track position promises job security, whereas, the nontenured is prone to job insecurity in the long run. Professors have discussed this question in both private and public universities that tenured position assures job security which is not promised in the nontenured position. In both areas, assessment of faculty performance relies heavily on teaching, scholarship, and service. As a nontenured faculty in my private university, I have been reappointed, given merit, and promoted based on my teaching, scholarship, and service. Yes, the mechanics of faculty evaluation is built on the agreed process between the faculty and the administration where school personnel representing faculty, department chairs, the deans, the senate faculty committee, provide their fair and equitable summative assessment to the provost, who consequently submits his judgment to the president for final determination. Indeed, I like such the rigorous evaluation, and with the pressure that my reappointment, merit, and promotion are based on what I do in teaching, scholarship, and service, I work hard to make sure that my performance exceeds expectations on all areas. Admittedly, I am aware that some members of the faculty prefer the tenure track to nontenure-track, but I do not see the value if the proper tools are well applied in the last days of one's contract to determine merit, promotion, and reappointment. I believe that whether a faculty is tenured or nontenured, the quality of their performance in teaching, scholarship, and service, should be used to determine the longevity of their stay at any given university or college. The heart of the matter is that faculty whether tenured or nontenured faculty should employ best teaching practices to meet the academic needs of the diverse student populations in our universities, and at the same time faculty should to exceed expectations in teaching, scholarship, and service. Therefore, I desire to give a personal reflective case to demonstrate from a practical viewpoint that non-tenured track position is a viable alternative for a tenure-track position.

\section{METHODOLOGY}

This research takes the interpretive/constructivist paradigm which utilizes an interpretive understanding of human experience (Mertens, 2014; Denzin, 2010; Haverkamp, \& Young, 2007; Mackenzie \& Knipe, 2006; Morrow, 2007; Creswell et al., 2006; Mertens, 2005) and it relies on the participants worldview of the phenomenon studied, and it does not start with a known theory, but instead, it develops theory or patterns of meanings (Jennings \& Junek, 2007; Creswell et al., 2003). The constructivist research uses qualitative data collection methods which include, collecting data from reports, case studies, ethnographic studies, records, analyzing written study on the subject under investigation, interviews, participant observations, and the like (Sloan \& Quan-Haase, 2017; Thanh \& Thanh, 2015; William, 2015; Mertens, 2014; Lincoln \& Guba, 2013; Terrell, 2012; Denzin, 2010; Haverkamp, \& Young, 2007; Mackenzie \& Knipe, 2006; Creswell, et al., 2006; Mertens, 2005). This study relied on the interpretivist/constructivist and case study research paradigms because it interpreted the researcher's case in his everyday real life experiences and knowledge as a nontenured professor at a private university, and constructed patterns of meanings from written research, student faculty evaluations, and the record of the researcher's performance in terms of teaching, scholarship, and service (Flick, 2018; Thanh \& Thanh, 2015; Mertens, 2014; Lauchner, Peterson, \& Kruper, 2012; Brown, 2008; Morrow, 2007; Mertens, 2005).

\section{LITERATURE REVIEW}

\section{The Definition of Non-Tenure Track Position}

The non-tenure track position in the study of McMurtry and McClellant (1997) is presented as

"faculty as either part-time or full-time faculty whose positions were ineligible for tenure" (McMurtry \& 
McClellant, 1997, para. 13; Peterson, 2007). The proponents of tenured track perceive that the nonetenured faculty, who are part-time and full-time, undermine the tenure track because they do not have control over curriculum and teaching, and that it gradually weakens the professional rank of full-time tenured faculty members. Further, these non-tenure track faculties are less trained and may not identify strongly with the teaching profession. The problematic situation of non-tenured track faculty as described by McMurtry and McClelland (1997) is that "As compared to tenure-track faculty, they tend to have lower salaries, fewer fringe benefits, worse job security, and little influence over the curriculum they are responsible for teaching" (Pratt et al., 1992, para.14). Moreover, these non-tenured faculty have a hard time publishing their academic work, respect from their senior colleagues, and blurred and changing work environment (Long, 1998).

Normand (1998) defined non-tenured track position to "include temporary and permanent part-timers as well as temporary and permanent full-timers ...." (para.3). From 1995 through 1998 Normand affirmed the need to include non-tenured faculty in the national forums by creating concerted efforts of seeking ways of dialogue regarding improving the working conditions of non-tenured faculty. To climax Normand's support for developing the working condition of non-tenure track position, at the NTT SIG for the 1997 CCCC in Phoenix, Arizona meeting three practical solutions, which included (1) improving our communication, (2) increasing our visibility, and (3) making connections (para. 4). The focus of these efforts was to communicate through publications of the organization, to include non-tenured faculty in the leadership, and to building connections by building coalitions within their national committees.

\section{Performance and the Mistreatment of the Non-Tenure Faculty}

A study by Raehl, MacLaughlin, \& Bond (2003) highlighting the upgrading nontenure-track pharmacy practice faculty from second-to first-class citizens demonstrated that "Newest pharmacy practice faculty members are appointed on a non-tenure" (para. 1). Also, the study stated the reason for the non-tenure track was based on the fact that "Without nontenure-track pharmacy practice faculty, new and established schools cannot offer quality patient-oriented pharmaceutical education" (para. 1). The study recognized that these non-tenure track faculty were treated as second-class citizens. The study points out that the responsibility of upgrading non-tenure track position rested on the school deans, departmental chairs, the non-track faculty members, and the tenured faculty.

Further, this study reveals that non-tenure track faculty have done well in their clinical practice and teaching. They do better in didactic instruction than the tenured faculty, they assume school and departmental leadership positions, their compensations for their services include negotiation and are awarded favorable contracts, they are encouraged to present a detailed faculty development plan, and they are encouraged to balance teaching, practice, and scholarship. On the other hand, the study portrayed that the tenure track faculty have acknowledged non-tenure track faculty as full members of the academic within their departments, senior tenured track faculty have been encouraged to promote the non-tenure track faculty members, and that the senior tenured faculty should avoid "we," and "they" relationships within the departments.

\section{How Growth of Non-Tenure Track Position Compares with Tenure Track Position}

Today, "Lecturers, adjuncts, instructors, postdocs, visiting professors, graduate student teachers, and others in non-tenure-track positions now constitute the great majority of faculty in US higher education" and the prophecy has it that the increase of non-tenured faculty is inevitable (Flaherty, 2013; Besosa, 2011, para.1; Kezar, \& Sam, 2010; Merrion, 2009; Maynard \& Joseph, 2008; Gapper, 2008; Gapper, 2000). As early as 1940s, Bososa, Bousquet, Barnes, Newfield, Nienow, Thomson, and Bradley (2009), in their study conversion of appointments to the tenure track, demonstrated that the principles of academic freedom and tenure was characterized by a nature system which provided permanent assurance of certainty in terms of long term employment and the security thereof. Irrefutably this premise became a source of attraction for both men and women into the higher education faculty job market. Hence, "The tenure system was designed to secure reasonable compensation and to protect academic freedom through continuous employment;" and, "Financial and intellectual security enabled the faculty to carry out the 
public trust in teaching and research, and it provided a system of professional peer scrutiny in hiring, evaluation, and promotion" (Besosa et al., 2009, para. 1-2). Today, with the collapse of the tenure track position system, the emergent of non-tenure track position trend has emerged, and various studies indicate that it is here to stay, for it has taken a life of its own (Goldenberg, 2011; Besosa, 2009; Carvalho \& Diogo, 2018). On the same thread, Maynard and Joseph (2008) in agreement with Benjamin (2002) concede that the proportion of full-time faculty and adjuncts or part-time faculty is " $40 \%$ and $45 \%$, and that in the community colleges part-time faculty has outnumbered full-time faculty considerably Maynard \& Joseph, 2008, para.1; Gapper, 2000; Kezar \& Sam 2011). Benjamin (2002) discussing that "... almost 50 percent of first-time students begin their higher education" and that "about 63 percent of instructors are part-time appointees" adds that "even in four-year institutions, nearly half of all instructional staff are either part-time faculty or graduate assistants" (para.5).

Consequently, the study on non-tenure track position in the higher education is of great magnitude as we see the increase of non-tenure positions and the decrease of tenure positions (Gapper, 2008; Gapper, 2000). The McMurtry and Mcclellant (1997) study on trends in student-faculty ratios and the use of nontenure-track faculty in MSW programs, shows a sharp decrease of tenure track faculty position. Further, the study showed that there was an increase of non-tenured position as stated in their report. Their findings included, (a) that the median ratio of students to faculty in MSW programs has grown $36 \%$ since 1981 and, for the past five years, has exceeded the Council on Social Work Education's recommended maximum; (b) that since 1978, the number of full-time tenure-track faculty has declined by nearly $8 \%$ despite sharply increased student populations; and, (c) that the number of part-time faculties has increased, but not in proportion to the number of students (McMurtry \& McClelland, 1997, para.1).

On the same breath, Beardsley and his colleagues Matzke, Pharm, Rospond, Williams, Knapp, Kradjan, Brazeau, (2008), investigating Factors Influencing the Pharmacy Faculty Workforce found that $62 \%$ of full-time faculty in the pharmacy practice were classified in the non-tenure track position. Since the trend of having more non-tenured faculty (whether they are full-time, adjuncts or part-time) in our universities and colleges is increasing rapidly, these institutions of higher learning must provide alternative ways of securing academic freedom and job security for the un-tenured faculty as they have done to the tenured faculty. The purpose is to meet the protections assured in the 1915 and 1940 declarations which tie academic freedom to tenure (Carvalho \& Diogo, 2018; Benjamin, Nails, Schrecker, Nelson, Rabban, Rhoades, \& Levy, 2011).

As early as 2018 as shown in figure 1, AAUP report shows that there is a decline of tenure position depending on the institution type. All combined, part-time, and full-time non-tenured-track regardless of education, is the highest; whereas, the tenure-track have dwindled. 


\section{FIGURE 1}
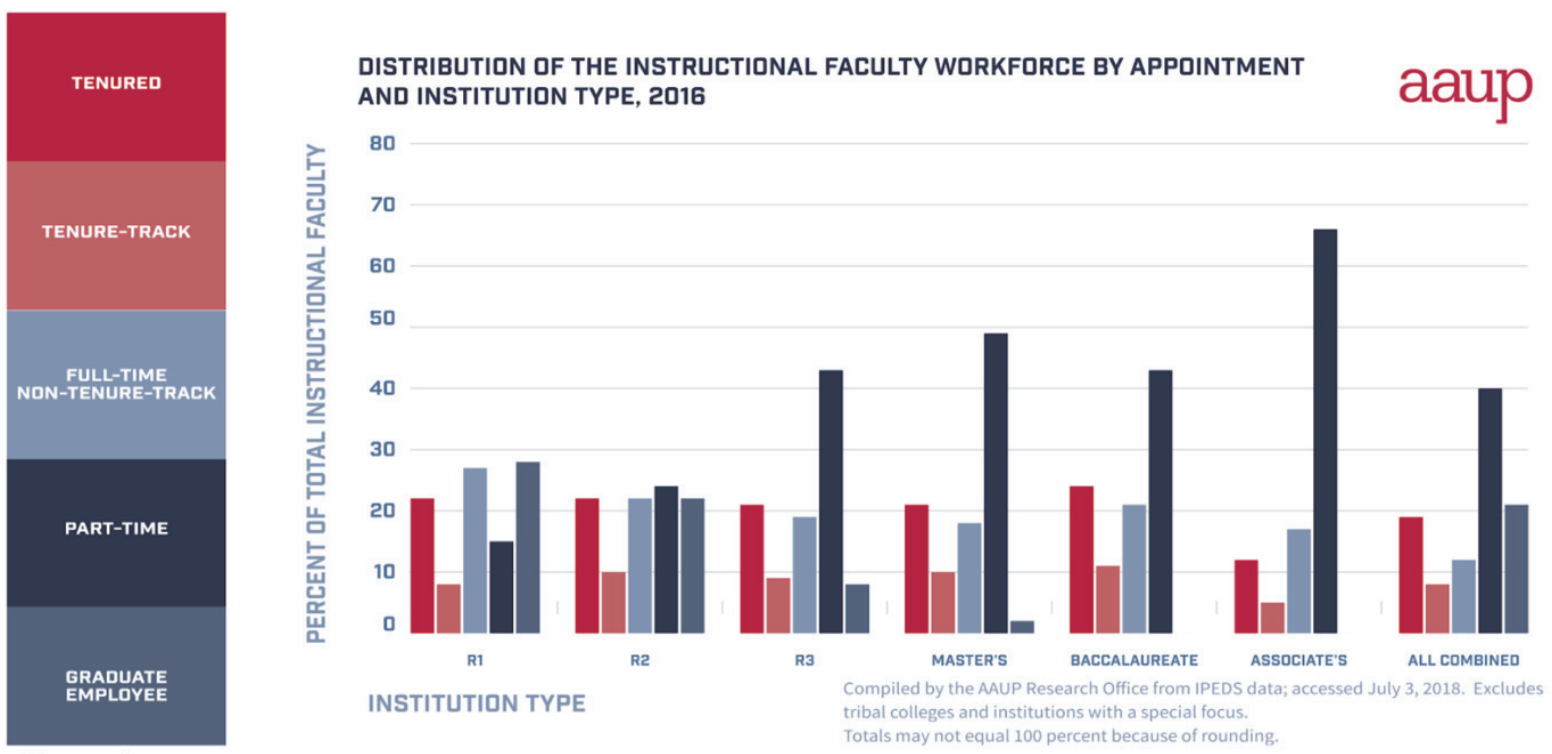

Figure 1

Adapted from Flaherty, C (2018). A Non-Tenure-Truck Position? Inside Higher Ed.

\section{What Tenure Track Position Offers}

One of the downsides of tenure track positions as found in the study, is tenure justified? Moreover, an experimental study of faculty beliefs about tenure, promotion, and academic freedom by Shermen (2006), found that "tenure can be described, at least in part, as a double-edged sword;" and that it is "a reward so highly motivating that it helps attract high-caliber professionals to the academy, but also a reward so eagerly anticipated that it could at times engender nonoptimal outcomes such as forgoing one's rights, freedoms, and responsibilities" (p. 568). Further, the tenure track positions in higher education represent "the crown jewel of academic life. It confers on those lucky enough to have it a lifetime of financial security and, purportedly, substantial freedom to teach and conduct research" (Shermer, 2006, p.553; Michaelsen, 2000). These substantial benefits allow the tenured faculty ability and freedom to choose the courses to teach and when to teach them, to secure a handsome salary and an assurance of professional life and rank.

Indeed, the results of Shermer's study (2006) continued to affirm that, (1) Assistant professors are more likely to engage in weak behaviors such as ignoring evidence of wrong-doing that are full professors, and the reverse is true of strong tactics such as confronting the wrong-doer; (2) untenured assistant professors and tenured associate professors believed their cohort was less likely to insist on academic freedom than the full professors' cohort; (3) full professors were not as brazen as junior faculty believed, and lower-ranked professors were timider than full professors believed; and, that (4) the lure of tenure and promotion seems to have muzzled lower-ranked professors, who were more reluctant to report ethical misconduct and relatively more willing to abandon unpopular teaching and research (Shermer, 2006, p. 565; Secret, Leisey, Lanninng, Polich \& Schaub, 2011).

\section{How non-tenure and tenure track position enhance teaching, scholarship, service, and professional effectiveness}

Does Tenure Track Position Enhance Teaching, Scholarship, And Service? While the non-tenured faculty in higher education do not have the privileges their tenured counterparts have, the studies show that they work more and do a thorough and a balanced job in teaching, practice, and scholarship (Raehl, MacLaughlin, \& Bond, 2003; Beardsley, Matzke, Pharm, Rospond, Williams, Knapp, Kradjan, Brazeau 
(2008).). However, the most significant question here is that does tenured or non-tenured track positions promote or enhance teaching, scholarship, service, and in the overall, professional effectiveness?

A study by Premeauz, Shane, and Monday (2002) dealing with the Perspectives on Tenure: Tenure Versus Non-Tenured Tenure Track Faculty, found that both tenured and no-tenured disagreed that tenure helps in promoting teaching, research, and service excellence. However, the non-tenured agreed that the tenure track position hinders teaching excellence (Levin \& Shaker, 2011). While there was agreement that teaching is of greater importance than research and service, the tenured faculty disagreed that the longer a person is tenured, the less effective. In contrast, the non-tenured faculty moderately agreed. However, the study showed that "tenure permits bad teaching because many universities grant tenure to professors who are only marginal or average teachers but are prolific researchers" (para.16). Certainly, tenure does not promote research excellence, but there is agreement that it weighs more regarding rating and rewards more than classroom excellent.

On the other hand, non-tenured faculty believed that tenure hinders research excellence; whereas, tenured disagreed. Regarding service, both tenured and the non-tenured faculty opposed that tenure promotes "service productivity" (para.19). The study demonstrated that both the tenured and the nontenured faculty agreed that tenure is necessary, and that academic freedom should not be compromised (Areen, 2008; Michaelsen, 2000).

The biggest question for me in this study is that, if the tenure track position does not promote excellence in teaching, scholarship, and service, what does? For how long shall the tenured and nontenured faculty constantly fight over who is more effective in the higher education classroom? As a nontenured full-time faculty, I will present a reflective case analysis on my experience at a university in southern California as an Assistant professor, Associate professor, and full professor, as a means of demonstrating that what matters in my view is not tenure but what you do as a professional educator; provided that what you do enhances teaching, scholarship, and service equitably. I believe my reflections on the non-tenure position as a professor at a private university will be a compelling testament to the enhancement of teaching, scholarship, and service in a non-tenured work environment.

\section{PERSONAL REFLECTIONS OF NON-TENURED TRACK PROFESSOR AT A PRIVATE UNIVERSITY IN CALIFORNIA}

What Matters. Indeed, even with the threat of the new majority on nontenured faculty, the tenured faculty do not want to relinquish their professional security (Kezar \& Sam, 2010; Chait, 2009; Zhou \& Volkwein, 2004; Premeauz et al., 2002; Gappa, 2000), and who would? In contrast, the non-tenured faculty feel sorry for themselves that they are neglected, and their jobs are not secure. Nevertheless, several questions suffice the need for this study. Are the non-tenured faculty spending endless time in grumbling meddling about their non-tenured track positions instead of committing themselves to teach, scholarship, and service? Are the tenure track faculty effective educators in the higher education sector? Are the tenured faculty spending more time defending their positions than they are spending in teaching and engaging in job-related scholarship agendas? What about the tenured faculty's commitment to service at the level of department, school, the university and community? Why is it that the emphasis is "me" the tenured professional and not the students the learners and their futures? Are the tenured faculty productive or they have become what some researchers state as unproductive (Premeauz et al., 2002; Pears, 1999)? These are real questions to me because when I go in the four-corner classroom or an online teaching and learning environment - Blackboard Learning Management System, I want to be thinking about students and their learning processes rather than my position. This thinking allows me to be free in sharing my personal experience as a non-tenured professor. Students come first to me, and that is why I have worked in a private institution which currently does not offer tenure track teaching positions.

Moreover, I believe that the alternative non-tenure track position is equally competitive and rewarding. Studies have already shown neither tenured position nor non-tenured guarantees quality performance. However, studies have also shown that none-tenured faculty are productive and perform well in teaching, scholarship, and service (Premeauz et al., 2002;) 


\section{Humble Beginnings with the University}

I started working at university in 1998 as an adjunct. When I taught the first class, I didn't know that my career in higher education was going to be marked by a desire of teaching adults who already have careers and are transitioning into a new teaching career in the P-12 education field. Teaching was not new to me, but after taking several classes in the undergraduate and the graduate levels, I right away connected to students. Students appreciated my preparedness and teaching style. I loved my students, and they loved me. And, it was at the end of the same year I joined the university that the university's interest in me was created and this prompted the media and communication team came to my classroom to videotape my teaching practice.

Consequently, I was featured in the November 1998 magazine demonstrating effectiveness in teaching. As the university got interested in me, I became more involved in the university's goals, teaching effectiveness; peer-reviewed presentations and journals, and service. As a result, I applied for a full-time teaching position in 1999. Although I interviewed twice in the same year, I finally got the job, and by October 16, 1999, I was posted at the Costa Mesa Academic Center as an Assistant Professor in the Teacher Education Depart of the School of Education.

For sure, I didn't know whether the assistant professor position I took led to a tenured teaching position or not. But my two years' appointment was a sign that the position might be temporal and no guarantees about what happens after the two year's appointment. What do you do when you come in such a situation; and, you do not want to ask many questions to senior professors, the chair, or the dean? I very soon came to know that this teaching position was non-tenured and my continued work with the university was going to be based on my teaching, scholarship, and service (Premeauz et al., 2002; Neumann \& Terosky, 2007; Carvalho \& Diogo, 2018). Fear and uncertainty crept in me as I wondered about the security of my job. However, this new and unsecured environment didn't hinder me from being an effective teacher, engaging in educational research, and providing services to my academic center, department, school, the university, and the community around me.

In the following pages, I will show in-depth performance effectiveness in teaching, scholarship, and service; of which became the basis for my merit, reappointment, and promotion. The overall evaluation of my teaching, scholarship, and service exceeded expectations within the rank.

\section{Teaching}

\section{Costa Mesa Experience}

I was working at Costa Mesa as an assistant professor I was involved in the three areas of teaching, scholarship, and service. Unquestionably my job security in this university was going to depend if my overall performance met or exceeded the expectations in teaching, scholarship, and service. Fortunately, when I came on board, I met a generous senior un-tenured professor Q who mentored me by showing that I needed to perform well at above 4.0 out 5.0 in teaching, scholarship, and service. Indeed, this marked the beginning of my success in my un-tenured track position. First of all, I must confess that teaching is my strongest area at this point. I knew that I was going to do well in teaching because in my adjunct years I connected with students by applying relevant pedagogical skills in teaching, meeting their academic needs, responding to their questions, providing prompt and clear feedback, and being there for them as their academic leader. With courses where I performed below 4 points according to students' assessment of my teaching, I investigated, analyzed, critically evaluated my teaching. As a result of this review, I applied best teaching practices to improve my content delivery, responding to students' questions promptly, and providing feedback to students work on time, hence opening a gateway for them to learn effectively, and consequently, my teaching effectiveness increased remarkably. I must articulate that I was not under any senior faculty, chair of my Teacher Educational Department, or dean. Indeed, his was my initiative to become the best educator there is in higher education. However, you have to notice that by being right in teaching does not equal being useful in scholarship. In the evaluations, students used Dr. Mbuva, but I will use Dr. M to avoid monotony. 


\section{Student Evaluations}

Under teaching, students' evaluations helped me become a better higher education teacher. Some of these statements are very encouraging and motivating. For instance, students in their evaluation wrote that the instructor was extremely knowledgeable and helpful. He was easy to approach and provided immediate feedback. He is one of the best instructors I've had at my university. Great hire! Dr. M is a highly knowledgeable professor who provided this course with not only personal, cultural experience but important research and resources that assisted us throughout the course. Other students added that the instructor was well prepared for classes, very organized, articulate, and knowledgeable about the subject matter. He used a strong personality to connect with students and his ability to capture the attention participations of all students by using various teaching strategies and techniques. It was a great pleasure to be in his class. He is an excellent asset to NU. Dr. M countenance within the classroom is incomparable. He genuinely cared about the students and had a passion for what he taught. Dr. M challenged me to think and speak more critically during class discussions. Dr. M is so knowledgeable on all educational levels \& subjects. I enjoyed the class. Dr. M utilized great resources and provided educational insights to multicultural diversity. He asked questions that provoked higher level thinking. Overall, I enjoyed the course and looked forward to having another class with Dr. M. This class was an intense class for the amount of time we had to complete our theses. I have gained so much information that will help me as a future educator. Professor $\mathrm{M}$ demonstrated professionalism at all times. His thesis template provided me the needed support to complete this assignment.

Other students commented that in the Overall - my writing and research skills have significantly improved - and I have gained a lot better understanding of diverse learners. The instructor provided personal experiences and offered one-on-one assistance for all students. Dr. M is a great instructor. He is always thorough, and he is very willing to help his students by solving problems. Indeed, Dr. M is an excellent instructor and a very personable man. Certainly, this is an excellent instruction - phenomenal experience. Others stated thank you so much for the responsive - thoughtful input and guidance. I learned a lot about teaching styles and about myself. I am going to go to the field more confident.

Yes, professor $\mathrm{M}$ is my favorite professor at National. I enjoyed the course. The course was challenging yet insightful. He was great. Dr. $\mathrm{M}$ is a great professor. I came to this course reluctantly after being out of college for over 20 years. This course has renewed my motivation to become a teacher that is so much needed. Dr. M will be the one instructor who is a significant influence on my education. Thank you, Dr. M., Finally, some of the students concluded that Dr. M is a great teacher, very receptive to students and always available for questions. He is a great teacher and very knowledgeable. Dr. M was my first instructor here at National, and now he is my last. He was a wonderful instructor from first to last. I cannot say enough good things about him. I was more nervous about this thesis than almost anything I have ever experienced. He made me feel at ease and helped me through it all! Thank you, Dr. M.

In contrast, students also gave suggestions concerning comments which demonstrated that I needed to work on my teaching delivery. For instance, students would say that Dr. $M$ is a great instructor. A suggestion for future classes - Dr. M should meet with the class at the beginning of the cohort to establish what will be required for the thesis. Most people have never done one and therefore have little knowledge as to what it takes. It would be helpful to choose a topic and do some research earlier on. One of the students said that I spend more time on discussion, while other suggested that I need to limit students going off on target about lives (the professor for input asked, i.e., student asking about advice for raising a 15-year-old son and the whole class). Some students continued to show that class was frequently off topic and did not coincide with syllabus assignments and grading was unclear. Having chapter two due at the beginning of week 3 was a difficult task to accomplish. Some of us take a great deal of time to present a written piece of work and to read through 30 sources. Not to mention time limitations, and work, etc. Some students work slower than others-please- please be aware of that! Others concluded that they felt little boxed in the formatting of the writing procedure, but it was a good learning experience. This course part of it needs to be presented at least by the 3-4th class to prepare more and start doing research and to be able to do more on the final research paper. Time was too short. I felt too rushed- I would prefer more time for research and writing. 


\section{Use of Students' Evaluations on Teaching}

I used student positive comments to see where I was doing good and continued to apply good teaching principles; whereas, students' suggestions of which I do not term as negative informed me of my weaknesses and helped me to improve and reach all students at all levels of learning. Hence, in the overall, the record of my teaching has demonstrated commitment, rigor, rapport with students, employment of various best teaching practices, competence, favor, motivation, knowledge of the content - subject matter, and diversity.

\section{Scholarship}

So, what did I do with the scholarship? I examined the courses that I taught and found out that they were dealing with issues of teaching, learning, diversity, equity, cultural change, and various issues in educational research. I began to listen to students' questions, tied that with my teaching experience in K12 classrooms, hence I found my niche in research. Inevitably, this led me to the process of developing my research agendas.

\section{Current Scholarship}

My current scholarship performance included publication in peer-refereed journals such as Mbuva, J. (2018). Education Makes the Difference: Analyzing the Emancipation, Gender Roles of Kenyan Women, and their Rise to positions of Power in the Wake of Educational Advantage and Constitutional and Government Devolvement in Kenya. Journal of Higher Education Theory and Practice, 18(4) 102-117. Mbuva, J. (2017). Exploring Teachers' Self-Esteem and Its Effects on Teaching, Students' Learning and Self-Esteem. Journal of Higher Education Theory and Practice, 17(3) 123-134. Mbuva, J. (2015). Examining the Effectiveness of Online Educational Technological Tools for Teaching and Learning and the Challenges Ahead. Journal of Higher Education Theory and Practice, 15(2), 113-127. Mbuva, J. (2014). Online Education, Progress, and Prospects. Journal of Business and Educational Leadership, 5(1), 91-100. Mbuva, J. M. (2012). Investigating the Dynamics of Mobile Learning and the Technology Driving its Effectiveness in Teaching and learning. National Social Science Technology Journal, 2(2). Mbuva, J. (2012). An examination of parental training and involvement in children's education. National Social Science Journal, 38(1), 39-45. Mbuva, J. (2012). An examination of student retention and student success in high school, college, and university. Journal of Higher Education Theory and Practice, 11(4), 92-101. The Phenomenon of Self-Esteem and How to enhance it in the Classroom. The Journal of the Advancement of Educational Research, 5(1), 11-18. Mbuva, J. (2009) Education and Emancipation of Kenyan Women in the Modern Era. Journal of Business and Educational Leadership, 1 (1) 105-114. Mbuva, J. (2008). Teacher Burnout and its Effects on Teaching in K-12 Educational System, Journal of Business and Behavioral Sciences, 19 (2). Mbuva, J. (2008). Educating Students of Color in Higher Education Opens Doors for Fairness, Equality, and Global Economic Opportunity. National Social Science Journal, 30(2) 81-87. Mbuva, J. M. (2007). Education Enhances Equality and Fairness: Where Do People of Color Fit in Global Educational Systems. In M. Christopher Brown II (Ed.) 2008). Still Not Equal: Expanding Educational Opportunity in Society (pp.381-391). New York: Peter Lang Publishing Inc. Mbuva, J. (2006). Diversity in the Classroom and its Effects on Teaching and Learning. National Social Science Perspective Journal, 32(2). Mbuva, J (2005). Teaching Our Children Conceptual Frame of Thinking: A new wave in Critical Pedagogy. National Social Science Association Journal, 25(1)138-143.

\section{Earlier Scholarship}

My earlier scholarship in peer-reviewed journals included Mbuva, J. (2003). Implementation of the Multiple Intelligences Theory in the 21st Century Teaching and Learning Environments: A New Tool for Effective Teaching and Learning in All Levels. (ERIC Document Reproduction Service No. ED476162). Website: http:/www.lib.ied.edu.hk/edarticle/multi.htm; Mbuva, J. (2002). Transforming Schools: The Need for Critical Pedagogy in the 21st Century Education. National Social Science Association Journal, 22(1) 60-66. Website: www.nssa.us/nssajrnl/22-1/htm/09.htm; Mbuva, J. (2002). The inclusion of Gardner's Multiple Intelligences across the Curriculum in the 21st Century Classroom: Leaving no 
Student out of the Learning Loop. National Social Science Association Journal, 20(1) 63-71. Website: www.nssa.us/nssajrnl/20_1/ html/Multiple_Intelligences_Mbuva.htm; Mbuva, J. (2002). An Evaluation of the Contributions of Peter McLaren and Joan Wink in the Critical Pedagogy Dialogue. National Social Science Perspective Journal, 22(1); Mbuva, J. (2001). An examination of academic rigor, excellence, and student performance in higher education. National Social Science Association Journal, 17(1) 59-71. Website: http://claxton.apsu.edu/NSSAJ/NSSAJ171/NSSAJ171PDF/NSSAJ17_1_8.pdf;Mbuva, J. (2001). Positive Ways of Recruiting and Retaining Teachers for the 21st Century Teaching Profession. National Social Science Journal, 19(1) 76-88. Website: http:/www.nssa.us/nssajrnal/19-1/htm/11/11.htm; and, Mbuva, J. (2001). Investigating Diversity in American institutions: Going beyond awareness and acceptance. National Social Science Association Journal, 19(2) 97-101. Website: www.nssa.us/nssajrnl/19_2/pdf/ Final_Invest_Div_American_Inst_Mbuva.pdf. Mbuva, J (2005). Teaching Our Children Conceptual Frame of Thinking: A new wave in Critical Pedagogy. National Social Science Association Journal, 25 (1)138-143. Mbuva, J. (2003). Implementation of the Multiple Intelligences Theory in the 21st Century Teaching and Learning Environments: A New Tool for Effective Teaching and Learning in All Levels. (ERIC Document Reproduction Service No. ED476162). Website: http://www.lib.ied.edu.hk/edarticle/multi.htm; Mbuva, J. (2002). Transforming Schools: The Need for Critical Pedagogy in the 21st Century Education. National Social Science Association Journal, 22(1) 6066. Website: www.nssa.us/nssajrnl/22-1/htm/09.htm; Mbuva, J. (2002). The inclusion of Gardner's Multiple Intelligences across the Curriculum in the 21st Century Classroom: Leaving no Student out of the Learning Loop. National Social Science Association Journal, 20(1) 63-71. Website: www.nssa.us/nssajrnl/20_1/ htm1/Multiple_Intelligences_Mbuva.htm; Mbuva, J. (2002). An Evaluation of the Contributions of Peter McLaren and Joan Wink in the Critical Pedagogy Dialogue. National Social Science Perspective Journal, 22(1); Mbuva, J. (2001). An examination of academic rigor, excellence, and student performance in higher education. National Social Science Association Journal, 17(1) 59-71. Website: http://claxton.apsu.edu/NSSAJ/NSSAJ171/NSSAJ171PDF/NSSAJ17_1_8.pdf;

Mbuva, J. (2001). Positive Ways of Recruiting and Retaining Teachers for the 21 st Century Teaching Profession. National Social Science Journal, 19(1) 76-88. Website: http://www.nssa.us/nssajrnal/191/htm/11/11.htm; and, Mbuva, J. (2001). Investigating Diversity in American institutions: Going beyond awareness and acceptance. National Social Science Association Journal, 19(2) 97-101. Website: www.nssa.us/nssajrnl/19_2/pdf/Final_Invest_Div_American_Inst_Mbuva.pdf.

It is worth informing the reader and the advocates of academic freedom in research that throughout the processes of research undertaking, I experienced freedom and I enjoyed the opportunity of allowing research to open my eyes to the body of knowledge in higher education teaching and learning, teacher training programs, and consequently the new knowledge enhanced my teaching effectiveness. This to me was phenomenal, and I have continued to do research pertinent to my teaching profession, teacher education, teaching and learning, diversity and equity, and cultural change in our political, economic, and cultural, linguistic, and social environments; upon which explicit, implicit, and hidden curricular of schooling rest. Indeed, positive engagement in scholarship helped me in enhancing my gaining new higher education knowledge, and effectiveness in scholarship.

\section{Service}

\section{Connecting to the Service Requirement}

Service was the third required part of my job description as a non-tenured assistant professor, associate professor, and full professor. There are no cuts about it, and one must meet or exceed the expectations of providing service at the assigned academic center or campus, Teacher Education Department, school, university, and the community. It was not easy to connect with this requirement because I was new at the university. As an assistant professor, I knew that I must very quickly start finding ways of getting involved in my teaching, scholarship, students' learning needs, and career advising, recruiting part-time faculty and mentoring them to enhance teaching effectiveness. I got involved in a nearby high school $\mathrm{M}$ as a regular visiting speaker to share about culture, and United States schooling experiences, engaged in the processes of increasing student enrollment by establishing off-site 
cohorts, etc. I enjoyed doing these services, but I was motivated by the fact that my job security rested upon reasonable service as a beginner. And, consequently, instead of this process of providing service at all levels hindering me from moving forward in my teaching career in higher education, it helped me in the method of enhancing my effectiveness in service.

\section{Service Requirement at the Academic Center Level}

In 2003 I was promoted to an Associate Professor non-tenured track position. My promotion to this new position was based on my effective teaching, scholarship, and service. To share a detailed account of my service as a non-tenured professor starting from 2003 till 2008, when I was promoted to full-time professor non-tenured track position, I effectively carried out all my responsibilities of being lead faculty for SOE/Teacher Education Department (educational programs) at the San Bernardino Academic Center. I fulfilled my duties as a lead faculty by recruiting new faculty and adjuncts for hire, and consequently evaluating and advising them. I staffed all MAT and MED courses and engaged in mentoring faculty and adjuncts, mentoring and counseling students concerning their studies, and educational career. Also, I was involved in leading the student teaching and Intern Programs at the center (seeing that they run smoothly) and recruiting field experience supervisors for both student teaching and intern programs, an organizing monthly departmental meeting; but mention a few. With the Intern Program, I have attended Intern Coaching training which enables me to model good teaching practices to faculty, adjuncts, field supervisors, and students. To be able to participate in the implementation of Teaching Performance Assessment (TPA), I have successfully trained, calibrated and certificated in all CA TPA TASKS, which include: Subject Specific Pedagogy, Designing Instruction, Assessing Learning, and Culminating Teaching Experience. At one time I had not received some of the certificates, and I asked Nick Pearson, CTC Professional Services, who confirmed, "Yes, you have successfully calibrated in both Designing Instruction and Culminating Teaching Experience." All of these activities mentioned above are time and energy consuming, but I have enjoyed doing all of them and others unmentioned because I love serving students at my university.

At the Teacher Education Department level, I have served as the chair for the Search and Screen committee for several years. Here, I mobilized my committee team, and we were able to sort out from many resumes from teachers around the country, and together, we were able to bring on board qualified faculty for our department and consequently for the School of Education. My colleagues in the Teacher Education Department can attest to the success of bringing a diverse population of educators for my university. I served in the above committee for many years before ascending to the chair position. I also served as a member of the leadership team, which was able to oversee the program and collaborate with the faculty in the revision of curriculum, course syllabi, and working on CCTC and WASC accreditation documents. I enjoyed working with all members of our department because, in unity, we were able to accomplish a lot; and at the same time, we kept the uniformity of our curriculum across the state. I have been involved in the process of orienting our new faculty, mentoring them, and providing scholarship advisement. I have helped faculty write and publish their work in peer-refereed journals. Recently, I served as the Southern Region Leadership Team Chair.

\section{Service Requirement at the School/College Level}

At the School of Education level, I have been able to serve in the capacity of Academic Affairs Committee, School Personnel Committee, School of Education (SOE) Dean Search Committee (three times), SOE monthly meetings.

\section{Service Requirement at the University Level}

At my university level, I have served as an Academic Affairs Committee participating member, University Faculty Personnel Committee, Senate Faculty Research Committee, and the Senate Faculty Development Committee. I am approved by the Graduate Council as a Graduate Faculty. Hence, this appointment enhanced my ability to teach graduate courses, direct graduate research, advise graduate students, develop graduate programs and curricula, and eligibility to vote for members of the Graduate 
Council, and chair Graduate Council Committees and subcommittees. I have served as University Faculty Senate Personal, Senate Academic Freedom Committee, and the Undergraduate Academic Planning Committee.

\section{Service Requirement at the Community Level}

At the community level, I attended meetings at the school districts and teacher performance celebrations. I have collaborated with the recruitment team in my center in visiting schools and school districts to talk to leaders and teachers in an effort of starting the Master of Arts in Teaching in their school districts. We have been very successful in increasing enrollment at the San Bernardino center since 2003. Working with my academic center administrative leadership and student services, we've visited and started learning off-sites at Riverside School District, Corona - Norco School District, Yucaipa School District, Hemet School District, Homeland School District, Arrow Head School District (Rim of the World High School), Colton School District, Rialto School District, Redland School District, Fontana School District, and Etiwanda School District. By visiting and starting off-sites in these school districts, we've been able to enhance the good image of my university. In efforts reaching out to the community, 1 developed a warm relationship with Alice Birney Elementary School. Here, I have joined teachers in promoting reading throughout the curriculum. School leaders/teachers and students have written interesting letters showing their appreciation of the Reading with Children at Colton USD. I take the time to visit the school and participate in events which promote academic performance and reading. I have availed myself to Base Line High School. Here, I have engaged in mentoring teachers in teaching, and I have presented to students what it takes to succeed academically and in life. I have enjoyed these moments because they link me to the classroom experience; where I interact with real teachers and students. This experience prepares and enhances my understanding of P-12 learning experience, and consequently, it helps in the processes of equipping California teachers at my university. I have also continued to build the excellent image of my university nationally and internationally when I interact with myriads of professors. Through the National Social Science Association, I am a member of the general board and a member of the publication board. Here, I join my colleagues in planning seminars and peer reviewing of articles for publication. My presentations and publications have been used by both students and professors around the world. For example, Dr. Mourad, Professor of Cognitive Psychology, who is Vice Dean, and faculty of education and director of Center of Management and Organizational Learning at El-Sheikh University, has said, "There is no psychology research without Prof James M. Mbuva." He adds, "It is a slogan I always use with my students in all seminars. Be assured that literature and the researchers will forget neither your contributions nor your name as a pioneer in writing about almost all fields of psychology."

Dr. Mourad concludes, "May God give you peace of mind and long life as humankind is in need to a great mind like yours. You are one of the greatest psychologists in modern times." When I read the words spoken by this international educator, I feel that my service in the community is worthwhile. Although this information is valid in the scholarship column, I believe my scholarship has connected to the world community, and this has enhanced the good image of my university. I surely shed tears of joy when I read this commendation from the esteemed Dr. Mourad of El Sheikh University. I have not met him, but my scholarship has met him and others out there. Sure, this is good! I have been affiliated with the American Association of Colleges for Teacher Education (AACTE) as a member, and they have appointed me to be Institutional Representative (IR) for Membership. Also, I am an active member of the National Social Science Association, where I serve as a member of the general board and editorial board. Below, you will find the process of evaluating faculty for merit, reappointment, and promotion based on the rank of each faculty. 
TABLE 1

PROCESS OF EVALUATING FACULTY FOR MERIT

\begin{tabular}{|l|l|l|l|l|l|}
\hline Level \#1 & Level \#2 & Level \#3 & Level \#4 & Level \#5 & Level \#6 \\
\hline Faculty & Departmental & School & School/College & Provost & President \\
Originates & Chair & Personnel & Dean & & \\
the Process & & Committee & & & \\
by sending a & & (Faculty- & & & \\
3-page letter & & Peers) & & & \\
to the & & & & & \\
Department & & & & & \\
Chair & & & & & \\
\hline
\end{tabular}

Regarding merit, as shown in level \#1, the faculty wishing to be evaluated for merit originates the process by sending a 3-page letter detailing performance in teaching, scholarship, and service to the department chair. The department chair evaluates faculty performance and sends recommendations to the school personnel committee which is comprised of faculty - peers, who in turn evaluates and submits their recommendations to the Dean. The dean makes recommendations based on the faculty document, evaluations from the department chair, and school personnel, and presents recommendations to the provost. The provost evaluates the performance of all faculty, considers assessment of the chair, the school personnel committee, and makes recommendations to the president for the final judgments and determination of the merit request.

TABLE 2

PROCESS OF EVALUATING FACULTY FOR REAPPOINTMENT

\begin{tabular}{|l|l|l|l|l|l|l|}
\hline Level \#1 & Level \#2 & Level \#3 & Level \#4 & Level \#5 & Level \#6 & Level \#7 \\
\hline $\begin{array}{l}\text { Faculty } \\
\text { Originates } \\
\text { the Process } \\
\text { by } \\
\text { submitting }\end{array}$ & Chair & $\begin{array}{l}\text { School } \\
\text { Personnel } \\
\text { Committee } \\
\text { a dossier to } \\
\text { the } \\
\text { department } \\
\text { chair }\end{array}$ & School/College & Provost & University & President \\
Faculty & & \\
Personnel & & \\
Committee & & \\
& & Peers) & & & & \\
\end{tabular}

In level \#1, the faculty wishing to be evaluated reappointment originates the process by sending a dossier detailing performance accompanied by evidence in teaching, scholarship, and service to the department chair. The department chair evaluates faculty performance and sends recommendations to the school personnel committee which is comprised of faculty - peers, who in turn evaluates and submits their recommendations to the Dean. The dean makes recommendations based on the faculty document, evaluations from the department chair, and school personnel, and presents recommendations to the university faculty personnel committee (a committee of the Senate) (UFPC). The UFPC evaluates the performance of all faculty, considers evaluations of the chair, the school personnel committee. The dean and makes recommendations to the provost, who makes his/her recommendations of the performance of the faculty of all schools and considers the recommendations of all other parties before him then sends to the president for the final judgments and determination. This process is replicated in evaluating faculty for promotion in Table 3. 
TABLE 3

PROCESS OF EVALUATING FACULTY FOR PROMOTION

\begin{tabular}{|c|c|c|c|c|c|c|}
\hline Level \#1 & Level \#2 & Level \#3 & Level \#4 & Level \#5 & Level \#6 & Level \#7 \\
\hline $\begin{array}{l}\text { Faculty } \\
\text { Originates } \\
\text { the Process } \\
\text { by } \\
\text { submitting } \\
\text { a dossier to } \\
\text { the } \\
\text { department } \\
\text { chair }\end{array}$ & $\begin{array}{l}\text { Departmental } \\
\text { Chair }\end{array}$ & $\begin{array}{l}\text { School } \\
\text { Personnel } \\
\text { Committee } \\
\text { (Faculty- } \\
\text { Peers) }\end{array}$ & $\begin{array}{l}\text { School/College } \\
\text { Dean }\end{array}$ & Provost & $\begin{array}{l}\text { University } \\
\text { Faculty } \\
\text { Personnel } \\
\text { Committee }\end{array}$ & President \\
\hline
\end{tabular}

The above evaluating parties are going to be guided by whether faculty performance in teaching, scholarship, and service did not meet the expectations, met the expectations, or it exceeded the expectations. The awarding of merit, reappointment and the promotion is determined based on the set expectations for each rank (instructor, assistant professor, associate professor or full professor. Tables 4 , 5 , and 6 show clearly how evaluations are carried out.

TABLE 4

RECOMMENDATION AND DETERMINATION FOR MERIT

\begin{tabular}{|c|l|l|l|c|}
\hline $\begin{array}{l}\text { Expectations by } \\
\text { Rank }\end{array}$ & Did not meet & Met & Exceeded & Recommendations \\
\hline Teaching & Give reasons & Give reasons & Give reasons & $?$ \\
\hline Scholarship & Give reasons & Give reasons & Give reasons & $?$ \\
\hline Service & Give reasons & Give reasons & Give reasons & $?$ \\
\hline
\end{tabular}

In Table 4, the evaluators will examine the performance of all faculty on teaching, and scholarship, to determine whether the evidence presented in the 3-page letter did not meet expectations, met expectations, and exceeded expectation according to the requirements of faculty's rank. The evaluators present their final recommendations on merit to the next evaluator. They will write the recommendation column their determination; thus, removing the question (?) mark.

TABLE 5 RECOMMENDATION AND DETERMINATION FOR REAPPOINTMENT

\begin{tabular}{|l|l|l|l|c|}
\hline $\begin{array}{l}\text { Expectations by } \\
\text { Rank }\end{array}$ & Did not meet & Met & Exceeded & Recommendations \\
\hline Teaching & Give reasons & Give reasons & Give reasons & $?$ \\
\hline Scholarship & Give reasons & Give reasons & Give reasons & $?$ \\
\hline Service & Give reasons & Give reasons & Give reasons & $?$ \\
\hline
\end{tabular}

In Table 5, the evaluators will examine the performance of all faculty on teaching, and scholarship, to determine whether the evidence presented in the dossier did not meet expectations, met expectations, and exceeded expectation according to the requirements of faculty's rank. The evaluators present their final 
recommendations on reappointment to the next evaluator. They will write the recommendation column their determination; thus, removing the question (?) mark.

\section{TABLE 6}

\section{RECOMMENDATION AND DETERMINATION FOR PROMOTION}

\begin{tabular}{|l|l|l|l|c|}
\hline $\begin{array}{l}\text { Expectations by } \\
\text { Rank }\end{array}$ & Did not Meet & Met & Exceeded & Recommendations \\
\hline Teaching & Give reasons & Give reasons & Give reasons & $?$ \\
\hline Scholarship & Give reasons & Give reasons & Give reasons & $?$ \\
\hline Service & Give reasons & Give reasons & Give reasons & $?$ \\
\hline
\end{tabular}

In Table 6, the evaluators will examine the performance of all faculty on teaching and scholarship, and service to determine whether the evidence presented in the dossier did not meet expectations, met expectations, and exceeded expectations according to the requirements of faculty's rank. The evaluators present their final recommendations on promotion to the next evaluator. They will write the recommendation column their determination; thus, removing the question (?) mark.

\section{NON-TENURED TEACHING POSITION JOB SECURITY ASSURED THROUGH PERFORMANCE}

\section{Policy for Merits, Reappointments, and Promotions}

By faculty policy for merits, reappointments, and promotions, my teaching, scholarship, and service were assessed in 2003, and I was granted a reappointment for six years and promotion to an Associate Professor. Following the same procedures and the evidence of performance in teaching, scholarship, and service, I applied for promotion to full professor in 2008; and, consequently, I was promoted and reappointed for eight years. When I hit the rank of full professor, my responsibilities grew not only to perform exceedingly in all areas of teaching, scholarship, and service, but also to mentor, and support adjuncts, assistant and associate professors in their teaching, scholarship, and service. I can joyfully testify that I have mentored and supported faculty in all areas and as a result, these members of the faculty have excelled in teaching, scholarship, and service. On the other hand, I have continued to promote the university in the community, to increase enrollment through establishing off-site cohorts, improving teaching effectiveness, scholarship, and service.

\section{Job Security Based on Teaching, Scholarship, and Service}

In all these years at my university, I never worried about my tenure, because I came to know this truth, my tenure is my productive teaching, scholarship, and service to the university I love. My heart was always on teacher effectiveness and connecting to my students. My research agenda crystallized into teaching and learning, educational research, multiculturalism, cultural change, diversity, and equity. Instead of grumbling and meddling on the varied responsibilities I assumed at the university, I thought of and embraced new skills and opportunities which improved my teaching effectiveness, scholarship, and service. Instead of worrying about tenure as my job security, I reached out to new ways of being productive in teaching, scholarship, and service.

\section{Compensation Policy and The Assessment Process in Place to Ensure Non-Tenure Track Position Security \\ The Role of the University to Ensure Non-Tenure Track Position Security}

As far as my compensations were concerned, the university granted an overall $3 \%$ salary increase to all faculty, and additional salary increase based on one's performance in teaching, scholarship, and service. This salary award was unmatchable; and, I found that my salary which started at the low $43 \mathrm{k}$ 
grew considerably. Job security was not my worry, and the more I continued to perfect and promote effective teaching, scholarship, and service at all levels, the more assured was my freedom and job security.

During the process of the assessment of faculty performance at all levels, a policy of shared governance, which includes members of faculty and administration, is applied. The assessment of faculty performance in teaching, scholarship, and service are carried out by School Personnel Committees of all schools, Chairs, Deans, the University Faculty Personnel Committee, the Provost, and the President. In this process, each party passes recommendations to the other until the recommendations reach the president of the university. At the presidential level, the faculty members are given the final decisions regarding their merits, reappointments, and promotions. At all levels of the assessment process, members of the faculty can rebut any conclusions and recommendations made concerning their dossiers if there is an appearance of unfairness in the recommendations.

\section{Adherence to Faculty Policy}

To make sure that no faculty is left behind, and that faculty policy is adhered to, all members of the faculty are reminded about merits, reappointments, and promotions every year. Both the office of the Provost and University Senate provide a considerable number of orientations to all faculty regarding the procedures and requirements for the application of merits, reappointments, and promotions as per faculty ranks. In so doing, the university has provided a fair, friendly, and a healthy environment for all its members of the faculty.

\section{CONCLUSIONS AND RECOMMENDATIONS}

In overall, the studies have shown that tenured and non-tenured track positions are here to stay. However, the non-tenure track position is increasing; whereas, the tenure track position is dwindling. Respondents in various studies indicated that tenure provides job security, but it does not assure teaching, scholarship, and service effectiveness. Studies also agreed that non-tenured and junior faculty do well in teaching and clinical practices than their tenured counterparts who might do well in scholarship.

While tenure might suggest academic freedom and job security, university leaders and faculty should consider non-tenure track position which is based on performance in teaching, scholarship, and service. When best assessment practices of faculty performance are established and fairly carried out, it can provide a healthy working environment, good compensations in merits and reappointments, and the overall, job security. At my university, the faculty is in charge of the departmental and school programs. They develop, revise, and improve curricular to increase effectiveness in teaching. The university has provided all sizeable faculty amount for professional development. With this money, the faculty members conduct research connected to their areas of teaching, and they are encouraged to present in the peerrefereed national and international conferences and consequently publish. Based on the data presented in this study, when conducive working environments in higher education are established, non-tenured faculty will be productive and thus demonstrate excellence in teaching, scholarship, and service. Hence, faculty will promote and enhance effectiveness in all areas. In all seriousness, I believe that my university respects and treats faculty with dignity and this alone has boosted morale and faculty performance in all areas. Unless a faculty member has performed below expectations as per the contract and rank, no one misses merit pays, promotion, and reappointment. Nevertheless, whether one is in tenured or non-tenured track teaching effectiveness and scholarship creativity, and service should be promoted to enhance effectiveness, rigor, student retention and satisfaction in the universities and colleges (Popouch \& Abel, 2011, Umbach, \& Wawrzynski, 2005; Berbera, 2004; Ramsden, 2003; Centra, 1993; Weimer, 1990).

Indisputably, excellence in higher education should be promoted, and with the fairness, merit, and the rigor applied in the processes of evaluating non-tenured faculty's performance in teaching, scholarship, and service; faculty should never be worried about the longevity and the security of their jobs. Tenured faculty should never be deceived that securing tenure means specialism only in scholarship, but also in teaching effectiveness, and service. The term tenured-faculty should not be based on the duration and the 
security of holding a faculty position, but rather it should be based on professional effective which embraces, teaching, scholarship, and service that exceeds expectations across the board. Further, universities and colleges should employ equitable evaluation policy measures and diverse assessment teams made of faculty (peers), Senate, and administration to measure faculty effectiveness in not only scholarship but also in teaching and service.

Finally, the employment of the policy of shared governance in assessing faculty effectiveness in higher education is mandatory. When university administrations and faculty move away from titles to performance-based assessment, we have a better way of employing equitable measures of rewarding parttime and full-time faculty.

\section{REFERENCES}

Adams, M. L. (2006). The quest for tenure: Job security and academic freedom. Cath. UL Rev., 56, 67.

Areen, J. (2008). Government as educator: A new understanding of first amendment protection of academic freedom and governance. Geo. $L J, 97,945$.

August, L., \& Waltman, J. (2004). Culture, climate, and contribution: Career satisfaction among female faculty. Research in Higher Education, 45(2), 177-192.

Barbera, E. (2004). Quality in virtual education environments. British Journal of Educational Technology, 35(1), 13-20.

Beardsley, R., Matzke, G. R., PharmD., Rospond, R., Williams, J., Knapp, K., Kradjan, W., .. . Brazeau, D. (2008). Factors influencing the pharmacy faculty workforce. American Journal of Pharmaceutical Education, 72(2), 1-34. Retrieved from http://ezproxy.nu.edu/login?url=http://search.proquest.com/docview/211309303?accountid=25320

Benjamin, E. (2002). How over-reliance on contingent appointments diminishes faculty involvement in student learning. Peer Review, 5(1), 4-10.

Benjamin, E., Nails, D., Schrecker, E. W., Nelson, C., Rabban, D. M., Rhoades, G. D., \& Levy, A. (2011). Ensuring academic freedom in politically controversial academic personnel decisions. Academe, 97, 88-115. Retrieved from http://ezproxy.nu.edu/login?url=http://search.proquest.com/docview/896358110?accountid=25320

Bezos, M. (2011). Ways to organize non-tenure-track faculty. Academe, 97(6), 46-46. http://ezproxy.nu.edu/login?url=http://search.proquest.com/docview/909056858?accountid=25320

Bezos, M., Bousquet, M., Barnes, L., Nelson, C., Newfield, M., Nienow, J., . . Bradley, G. (2009).

Conversion of appointments to the tenure track. Academe, 95(6), 89-99.

http://ezproxy.nu.edu/login?url=http://search.proquest.com/docview/232306267?accountid=25320

Brown, P. A. (2008). A review of the literature on case study research. Canadian Journal for New

Scholars in Education/Revue canadienne des jeunes chercheures et chercheurs en education, 1(1).

Brown, R. S., \& Kurland, J. E. (1990). Academic tenure and academic freedom. Law and Contemporary Problems, 53(3), 325-355.

Carvalho, T., \& Diogo, S. (2018). Non-tenured Teachers, Higher Education

Centra, J. A. (1993). Reflective Faculty Evaluation: Enhancing Teaching and Determining Faculty

Effectiveness. The Jossey-Bass Higher and Adult Education Series. Jossey-Bass Inc., 350

Sansome St., San Francisco, CA 94104.

Chait, R. (2009). The questions of tenure. Harvard University Press.

Chait, R. P., \& Chait, R. P. (2002). Why tenure? Why now. The questions of tenure, 6-31.

Creativity. (n.d.). American Journal of Pharmaceutical Education, 66(1), 59. 
Creswell, J. W., Plano Clark, V. L., Gutmann, M. L., \& Hanson, W. E. (2003). Advanced mixed methods research designs. Handbook of mixed methods in social and behavioral research, 209, 240.

Creswell, J. W., Shope, R., Plano Clark, V. L., \& Green, D. O. (2006). How interpretive qualitative research extends mixed methods research. Research in the Schools, 13(1), 1-11.

Cross, J. G., \& Goldenberg, E. N. (2003). How does university decision making shape the faculty? New directions for higher education, 2003(123), 49-59.

Denzin, N. K. (2010). Moments, mixed methods, and paradigm dialogs. Qualitative inquiry, 16(6), 419427.

Ehrenberg, R. G., \& Zhang, L. (2005). Do tenured and tenure-track faculty matter? Journal of Human Resources, 40(3), 647-659.

Enders, J., \& Musselin, C. (2008). Back to the future? The academic professions in the $21 \mathrm{st}$ century. Higher education to, 2030, 125-150.

Flaherty, C. (2013). Making the case for adjuncts. Inside Higher Ed, 2-4.

Flaherty, C. (2018). A None-Tenure-Track Profession? Inside Higher Ed. Retrieved from https://www.insidehighered.com/news/2018/10/12/about-three-quarters-all-faculty-positions-aretenure-track-according-new-aaup

Flick, U. (2018). Designing qualitative research. Sage.

Gappa, J. M. (2000). The new faculty majority: Somewhat satisfied but not eligible for tenure. New directions for institutional research, 2000(105), 77-86.

Gappa, J. M. (2002). Academic Careers for the 21 st Century: More Options for new Faculty. In Higher education: Handbook of theory and research (pp. 425-475). Springer, Dordrecht.

Gappa, J. M. (2008). Today's majority: Faculty outside the tenure system. Change: The Magazine of Higher Learning, 40(4), 50-54.

Goldenberg, E. N., \& Cross, J. G. (2011). Off-track profs: Nontenured teachers in higher education. Mit Press.

Harper, E. P., Baldwin, R. G., Gansneder, B. G., \& Chronister, J. L. (2001). Full-time women faculty off the tenure track: Profile and practice. The Review of Higher Education, 24(3), 237-257.

Haverkamp, B. E., \& Young, R. A. (2007). Paradigms, purpose, and the role of the literature: Formulating a rationale for qualitative investigations. The Counseling Psychologist, 35(2), 265-294.

Haviland, D., Alleman, N. F., \& Cliburn Allen, C. (2017). 'Separate but Not Quite Equal': Collegiality Experiences of Full-Time Non-Tenure-Track Faculty Members. The Journal of Higher Education, 88(4), 505-528.

Jennings, G., \& Junek, O. (2007). Grounded theory: Innovative methodology or a critical turning from hegemonic methodological praxis in tourism studies. The critical turn in tourism studies: Innovative research methodologies, 197-210

June, A. W. (2012). Adjuncts Build Strength in Numbers. Chronicle of Higher Education.

Kezar, A., \& Sam, C. (2010). Special Issue: Understanding the New Majority of Non-Tenure-Track Faculty in Higher Education--Demographics, Experiences, and Plans of Action. ASHE higher education report, 36(4), 1-133.

Kezar, A., \& Sam, C. (2011). Understanding non-tenure track faculty: New assumptions and theories for conceptualizing behavior. American Behavioral Scientist, 55(11), 1419-1442.

Lauckner, H., Paterson, M., \& Krupa, T. (2012). Using Constructivist Case Study Methodology to Understand Community Development Processes: Proposed Methodological Questions to Guide the Research Process. Qualitative Report, 17, 25.

Levin, J. S., \& Shaker, G. G. (2011). The hybrid and dualistic identity of full-time non-tenure-track faculty. American Behavioral Scientist, 55(11), 1461-1484.

Levine, J. M. (1995). Voices in the Wilderness: Tenured and Tenure-Track Directors and Teachers in Legal Research and Writing Programs. J. Legal Educ., 45, 530.

Lincoln, Y. S., \& Guba, E. G. (2013). The constructivist credo. Left Coast Press. 
Long, C. D. (1998). The faculty at work. Academe, 84(4), 53-61. Retrieved from http://ezproxy.nu.edu/login?url=http://search.proquest.com/docview/232345607?accountid=2532 0

Mackenzie, N., \& Knipe, S. (2006). Research dilemmas: Paradigms, methods and methodology. Issues in educational research, 16(2), 193-205.

Maid, B. M. (2001). Non-tenure-track instructors at UALR: Breaking rules, splitting departments. Schell and Stock, 76-90

Maynard, D. C., \& Joseph, T. A. (2008). Are all part-time faculty underemployed? the influence of faculty status preference on satisfaction and commitment. Higher Education, 55(2), 139-154. doi: 10.1007/s10734-006-9039-z

McMurtry, S. L., \& McClelland, R. W. (1997). Trends in student-faculty ratios and the use of non-tenuretrack faculty in MSW programs. Journal of Social Work Education, 33(2), 293-207. http://ezproxy.nu.edu/login?url=http://search.proquest.com/docview/209778713?accountid=

McPherson, M. S., \& Schapiro, M. O. (1999). Tenure issues in higher education. Journal of Economic Perspectives, 13(1), 85-98.

Merrion, M. (2009). A prophecy for the arts in higher education. Change, 41, 16-21. Retrieved from http://ezproxy.nu.edu/login?url=http://search.proquest.com/docview/208047112?accountid=25320

Mertens, D. M. (2007). Transformative paradigm: Mixed methods and social justice. Journal of mixed methods research, 1(3), 212-225.

Mertens, D. M. (2014). Research and evaluation in education and psychology: Integrating diversity with quantitative, qualitative, and mixed methods. Sage publications.

Mertens, D.M. (2005). Research methods in education and psychology: Integrating diversity with quantitative and qualitative approaches. (2nd ed.) Thousand Oaks: Sage.

Michaelson, M. (2000). Should Untenured as Well as Tenured Faculty Be Guaranteed Academic Freedom: A Few Observations. $J C \& U L, 27,565$.

Morrow, S. L. (2007). Qualitative research in counseling psychology: Conceptual foundations. The Counseling Psychologist, 35(2), 209-235.

Musselin, C. (2007). The Transformation of Academic Work: Facts and Analysis. Research \& Occasional Paper Series: CSHE. 4.07. Center for studies in higher education.

Nelson, C. (2011). No university is an island: Saving academic freedom. NYU Press.

Nestor, P. I., \& Leary, P. (2000). The relationship between tenure and non-tenure track status of Extension faculty and job satisfaction. Journal of Extension, 38(4), 8-13

Neumann, A., \& Terosky, A. L. (2007). To give and to receive: Recently tenured professors' experiences of service in major research universities. The Journal of Higher Education, 78(3), 282-310.

Normand, D. B. (1998). The non-tenure-track faculty special interest group: Who we are and what we do. College Composition and Communication, 49(1), A2-A2. Retrieved from

$\mathrm{http}$ ://ezproxy.nu.edu/login?url=http://search.proquest.com/docview/220740093?accountid=2532 025320

Pearce, J. A. (1999). Faculty survey on business education reform. The Academy of Management Executive, 13, 105-109.

Peterson, M. R. (2007). Academic tenure and higher education in the United States: Implications for the dental education workforce in the twenty-first century. Journal of dental education, 71(3), 354364.

Popovich, N. G., \& Abel, S. R. (2002). The need for a broadened definition of faculty scholarship and

Premeaux, S. R., Shane, R. \& Mondy, R. W. (2002). Perspectives on tenure: Tenured versus nontenured tenure-track faculty. Journal of Education for Business, 77(6), 335-339. Retrieved from http://ezproxy.nu.edu/login?url=http://search.proquest.com/docview/202820539?accountid=25320

Purcell, M. (2007). "Skilled, Cheap, and Desperate" 1: Non-tenure-track Faculty and the Delusion of Meritocracy. Antipode, 39(1), 121-143 
Raehl, C. L. (2002). Changes in pharmacy practice faculty 1995-2001: implications for junior faculty development. Pharmacotherapy: The Journal of Human Pharmacology and Drug Therapy, 22(4), 445-462.

Raehl, C. L., MacLaughlin, E. J., \& Bond, C. A. (2003). Upgrading nontenure-track pharmacy practice faculty from second- to first-class citizens. American Journal of Pharmaceutical Education, 67(1), 799-800. Retrieved from http://ezproxy.nu.edu/login?url=http://search.proquest.com/docview/211223099?accountid=25320

Ramsden, P. (2003). Learning to teach in higher education. Routledge.

Roemer, M., Schultz, L. M., \& Durst, R. K. (1999). Reframing the great debate on first-year writing. College Composition and Communication, 50(3), 377-392.

Ross, A. (2011). Human Rights, Academic Freedom, and Offshore Academics. Academe, 97(1), 14-17.

Secret, M., Leisey, M., Lanning, S., Polich, S., \& Schaub, J. (2011). Faculty perceptions of the scholarship of teaching and learning: Definition, activity level and merit considerations at one university. Journal of the Scholarship of Teaching and Learning, 1-20.

Shermer, M. (2006). Testing tenure: Let the market decide. Behavioral and Brain Sciences, 29(6), 584584. Retrieved from http://ezproxy.nu.edu/login?url=http://search.proquest.com/docview/212235904?accountid=25320

Sloan, L., \& Quan-Haase, A. (Eds.). (2017). The SAGE handbook of social media research methods. Sage.

Tang, T. L. P., \& Chamberlain, M. (2003). Effects of rank, tenure, length of service, and institution on faculty attitudes toward research and teaching: The case of regional state universities. Journal of Education for Business, 79(2), 103-110.

Terrell, S. R. (2012). Mixed-methods research methodologies. The qualitative report, 17(1), 254-280.

Thanh, N. C., \& Thanh, T. T. (2015). The interconnection between interpretivist paradigm and qualitative methods in education. American Journal of Educational Science, 1(2), 24-27.

Thedwall, K. (2008). Nontenure-track faculty: Rising numbers, lost opportunities. New Directions for Higher Education, 2008(143), 11-19.

Umbach, P. D., \& Wawrzynski, M. R. (2005). Faculty do matter: The role of college faculty in student learning and engagement. Research in Higher Education, 46(2), 153-184.

Walliman, N. (2015). Social research methods: The essentials. Sage.

Weimer, M. (1990). Improving College Teaching: Strategies for Developing Instructional Effectiveness. The Jossey-Bass Higher Education Series. Jossey-Bass Inc., 350 Sansome St., San Francisco, CA 94104.

West, M. S., \& Curtis, J. W. (2006). AAUP faculty gender equity indicators 2006 (p. 85). Washington, DC: American Association of University Professors.

Zhou, Y., \& Volkwein, J. F. (2004). Examining the influences on faculty departure intentions: A comparison of tenured versus nontenured faculty at research universities using NSOPF99. Research in higher education, 45(2), 139-176.

Zhou, Y., \& Volkwein, J. F. (2004). Examining the influences on faculty departure intentions: A comparison of tenured versus nontenured faculty at research universities using NSOPF99. Research in higher education, 45(2), 139-176. 